Zeszyty Naukowe Szkoły Głównej Gospodarstwa Wiejskiego w Warszawie Problemy Rolnictwa Światowego tom 17 (XXXII), zeszyt 3, 2017: 137-144

DOI: 10.22630/PRS.2017.17.3.60

Wojciech Jarecki', Barbara Wyrzykowska²

${ }^{1}$ Uniwersytet Szczeciński

${ }^{2}$ Szkoła Główna Gospodarstwa Wiejskiego w Warszawie

\title{
Kompetencje menedżerskie w zarządzaniu spółdzielniami mleczarskimi
}

\section{Managerial Competencies in the Management of Dairy Cooperatives}

\begin{abstract}
Synopsis. Postępująca globalizacja, rozwój technologii, wahania koniunktury rynkowej to tylko niektóre trendy mające wpływ na tworzenie specyficznych wymagan kompetencyjnych wobec menedżerów. Spółdzielnie są ważnymi podmiotami na całym świecie, szczególnie w rolnictwie, a zwłaszcza w przetwórstwie mleka. Warto zatem zastanowić się, jakimi kompetencjami powinna wyróżniać się zatrudniona w nich kadra kierownicza, aby zapewniać im stabilny i długotrwały rozwój. Celem opracowania jest zaprezentowanie zestawu pożądanych kompetencji dla kadry kierowniczej w spółdzielniach mleczarskich. Do realizacji przyjętego celu oraz weryfikacji postawionych tez zastosowano analizę literatury krajowej i zagranicznej oraz badania eksperckie. Wśród kompetencji menedżerskich $\mathrm{w}$ spółdzielniach mleczarskich wyodrębniono: kompetencje osobiste wyznaczone cechami osobowymi, kompetencje społeczne związane ze stosunkiem do drugiego człowieka i kompetencje menedżerskie polegające na sposobie realizacji roli kierowników. Menedżerowie spółdzielni mleczarskich powinni posiadać szereg typowych kompetencji menedżerskich, takich jak: motywowanie, myślenie analityczne i strategiczne, orientacja w biznesie i orientacja na klienta oraz przywództwo.
\end{abstract}

Słowa kluczowe: kompetencje menedżerskie, kadra kierownicza, spółdzielnie mleczarskie, menedżerskie zarządzanie

\begin{abstract}
Increasing globalization, technological development, and market fluctuations are just some of the trends that influence the formation of specific competence requirements for managers. Cooperatives are important players in the world, particularly in agriculture, and especially in the processing of milk. It is therefore worth considering what competencies should be developed by managers employed in this industry, in order to provide them with stable and long-term opportunities. The aim of this article is to develop a set of desired competencies for executives in dairy cooperatives. The research included analysis of domestic and foreign literature and of research experts. Among the managerial competencies needed for dairy cooperatives were: personal competencies designated by personal qualities, social competencies related to inter-personal relationships and managerial competencies in the methods used by managers. Dairy cooperative managers should also have a number of typical managerial competencies such as motivation, analytical and strategic thinking, business orientation, customer orientation and leadership.
\end{abstract}

Key words: managerial competences, managers, dairy cooperatives, managerial management

\footnotetext{
${ }^{1}$ dr hab., prof. US, Katedra Zarządzania Kapitałem Ludzkim, Wydział Nauk Ekonomicznych i Zarządzania US w Szczecinie, ul. Mickiewicza 64, 71-101 Szczecin, e-mail: wojciech.jarecki@wneiz.pl

${ }^{2} \mathrm{dr}$, Katedra Ekonomiki i Organizacji Przedsiębiorstw, Wydział Nauk Ekonomicznych SGGW w Warszawie, ul. Nowoursynowska 166, 02-787 Warszawa, e- mail: barbara_wyrzykowska@sggw.pl
} 


\section{Wprowadzenie}

Spółdzielnie są ważnymi podmiotami gospodarczymi, szczególnie w rolnictwie, a zwłaszcza w przetwórstwie mleka. Nowe warunki ekonomiczne zmusiły spółdzielnie mleczarskie do podejmowania umiejętnych działań w różnych obszarach działalności, wykorzystując w tym celu posiadane zasoby i kompetencje. W związku z tym, przeobrażeniom uległy zadania i funkcje kadry kierowniczej $w$ tych podmiotach. Redefinicja roli kierowników wynika z wielu zjawisk, których źródłem są nie tylko zmiany otoczenia przedsiębiorstwa (Pocztowski, 2007, s. 45-50), ale także zmiany sposobu działania samych organizacji spółdzielczych. Transformacja otoczenia i organizacji powodują, że o sukcesie menedżerów decyduje wiele czynników, z których część jest związana ze specyficznym rodzajem kompetencji. Postępująca globalizacja, rozwój technologii, wahania koniunktury rynkowej to tylko niektóre trendy mające wpływ na tworzenie specyficznych wymagań kompetencyjnych wobec menedżerów. Warto zatem zastanowić się jakimi kompetencjami powinna wyróżniać się kadra kierownicza w spółdzielniach mleczarskich, aby zapewniać im stabilny i długotrwały rozwój.

\section{Cel pracy i metodyka badań}

W spółdzielniach mleczarskich nie ma opracowanego i wdrożonego katalogu kompetencji zgodnego z Polską i Europejską Ramą Kwalifikacji dla kadry zarządzającej i menedżerskiej. W związku $\mathrm{z}$ tym zespół ekspertów podjął się zadania, aby określić pożądane kompetencje dla menedżerów w spółdzielniach mleczarskich.

Celem opracowania jest zaprezentowanie zestawu pożądanych kompetencji dla kadry kierowniczej w spółdzielniach mleczarskich. W niniejszym artykule postawiono następującą tezę: kadra kierownicza w spółdzielniach mleczarskich powinna posiadać kompetencje istotne z punktu widzenia realizacji celów przedsiębiorstwa spółdzielczego oraz z punktu widzenia funkcjonowania w konkurencyjnej światowej gospodarce (procesów globalizacji).

Do realizacji przyjętego celu oraz weryfikacji tak postawionej tezy zastosowano analizę literatury krajowej i zagranicznej oraz badania eksperckie. Do utworzenia zestawu kompetencji zostało wykorzystane narzędzie „Profil Kompetencji” opracowane przez firmę doradczo- szkoleniową „Forfuture Consulting”. „Profil Kompetencji” jest narzędziem służącym do tworzenia profili kompetencyjnych dla dowolnych stanowisk, bazuje on na mapie kompetencji czyli zestawieniu 36 kompetencji na pięciu poziomach.

W opracowaniu zestawu kompetencji wzięli udział pracownicy naukowi z Katedry Ekonomiki i Organizacji SGGW w Warszawie i Katedry Zarządzania Kapitałem Ludzkim Uniwersytetu Szczecińskiego oraz praktycy z Krajowego Porozumienia Spółdzielni Mleczarskich, łącznie pięć osób. W trakcie kontaktu e- mailowego każdy z ekspertów dokonał wyboru kompetencji, które uznał za pożądane tzn. gwarantujące właściwą realizację zadań, charakterystycznych dla roli kierowników z tej branży a następnie zostało uzgodnione wspólne stanowisko w tej sprawie. 


\section{Uwarunkowania działalności spółdzielni mleczarskich}

Analizując kompetencje menedżerów w spółdzielniach mleczarskich należy zwrócić uwagę na uwarunkowania działalności tych podmiotów. Spółdzielnie mleczarskie są specyficzne z dwóch powodów. Po pierwsze w myśl prawa spółdzielczego, muszą zapewnić nie tylko zysk, lecz również zaspokoić potrzeby swoich członków - osiąganie przez nich maksymalnych cen za mleko (Dworniak, Pietrzak, 2014, s. 68). Po drugie, specyfika pracy menedżera w spółdzielni znacząco odbiega od warunków wykonywania zawodu menedżera w przedsiębiorstwie niespółdzielczym. Wśród istotnych różnic, należy wymienić przede wszystkim (Dyka, Grzegorzewski, 2000, s. 67):

- pracę menedżera pod stałą obserwacją członków spółdzielni, którzy stanowią najbardziej wpływową grupę interesariuszy, m.in. ze względu na obsadzanie kluczowych stanowisk,

- odmienne zasady podziału wypracowanego zysku, nadwyżka bilansowa podlega podziałowi na podstawie uchwały walnego zgromadzenia;

- konieczność uwzględnienia w procesie decyzyjnym tego, że zarówno klienci, jak i dostawcy są jednocześnie właścicielami; w spółdzielniach członkowie są nie tylko właścicielami, ale zwykle również pracownikami, usługodawcami lub usługobiorcami, mają przy tym szerokie uprawnienia decyzyjne i kontrolne,

- wśród bodźców brak motywacyjnych możliwości nabycia prawa własności do majątku spółdzielni; udziały nie uczestniczą $\mathrm{w}$ obrocie giełdowym i pozagiełdowym; udział w spółdzielni nie może być sprzedany, a jedynie może być członkowi zwrócony w wartości nominalnej,

- potrzebę efektywnej współpracy z członkami spółdzielni polegającą na częstej wymianie informacji dotyczących sposobów działania, aktualnych i przyszłych potrzeb oraz wyników finansowych spółdzielni, jak również wyboru kierunków rozwoju spółdzielni,

- specyficzny rodzaj przywództwa polegający na takim stylu współpracy, który przyciągnie członków i pracowników spółdzielni skłaniając ich do przedłużenia menedżerowi kontraktu; reelekcja prezesa i pozostałych członków zarządu zależy od tego, w jakim stopniu spełniają oni oczekiwania walnego zgromadzenia, co z oczywistych względów zmusza wspomniane osoby do kierowania spółdzielnią zgodnie z interesami ogółu członków.

Ponadto w ostatnim ćwierćwieczu, w polskim przemyśle mleczarskim, zaszły istotne przemiany, które można podzielić na trzy okresy (Pietrzak, Roman, 2014, s. 79):

- I fala przemian: „szok i dostosowanie do rynku” - zapoczątkowana wraz z transformacją całej gospodarki w okresie 1989-1990;

- II fala przemian: „dostosowanie do UE” - jako umowną cezurę czasową można przyjąć embargo UE na polskie mleko (1997) oraz wprowadzenie nowej zaostrzonej normy na mleko surowe w skupie (1998), co dało początek kompleksowym procesom dostosowawczym sektora do wymogów UE - które w zasadniczej mierze trwały do akcesji, a z uwzględnieniem okresów przejściowych do 2006 r.;

- III fala przemian; ,globalizacja” - związana z reformami WPR, zmierzającymi do stopniowej liberalizacji rynku mleka i otwarcia go na oddziaływanie rynku światowego, czego szczególnie znaczącym przejawem był skok cen w 2007 r.

Obecnie przed polskimi przedsiębiorstwami spółdzielczymi i ich kadrą zarządzającą stoi poważne zadanie zmierzenia się z konkurencją funkcjonującą od dziesięcioleci na rynkach światowych. Dynamiczne, globalne otoczenie (procesy integracyjne i globalizacyjne, w tym umiędzynarodowienie przedsiębiorstw) spowodowało wzrost 
znaczenia menedżerów i ich roli oraz podniosło standardy zarządzania organizacjami wraz z oczekiwaniami wobec kompetencji menedżerskich.

\section{Menedżerskie ${ }^{3}$ zarządzanie spółdzielnią}

Zarządzanie w przedsiębiorstwie spółdzielczym jest szczególnie złożonym procesem, wynikającym z przepisów prawa spółdzielczego. Organy spółdzielni dzielą się na organy właścicielskie oraz menedżerskie. W polskim prawie spółdzielczym układ organów menedżerskich zakłada model dualistyczny, a więc istnienie obok siebie dwóch organów menedżerskich, tj. zarządu i rady nadzorczej (Cioch, 2011, s. 67-68).

$\mathrm{W}$ ostatnich latach w spółdzielczości krytycznej ocenie poddawany jest tradycyjny model zarządzania przedsiębiorstwem spółdzielczym. Proces kompetentnego wykonywania zadań i ról ${ }^{4}$ zawodowych kadr kierowniczych ${ }^{5}$ spółdzielni (głównie członków rad nadzorczych, zarządów, kierowników wewnętrznych jednostek organizacyjnych spółdzielni)postępuje stosunkowo wolno (Bodak, Cierniak-Emerych, 2010, s. 82). O stosunkowo małej skuteczności i efektywności ich działań świadczy m.in. niższa zazwyczaj efektywność ekonomiczno- finansowa przedsiębiorstw spółdzielczych $\mathrm{w}$ stosunku do innych form prawno- organizacyjnych działających $\mathrm{w}$ tej samej branży (Czternasty, Czyżewski, 2007, s. 232). Brak zatem menedżerów których wymaga rynek tzn.: realizujących zmiany, rozumiejących i potrafiących je przeprowadzić, stwarzających podwładnym możliwość ujawnienia swoich kompetencji, kreatywności i zaangażowania.

Wewnątrzspółdzielcza bariera braku kompetencji skłania do rozważenia ustawowych możliwości wprowadzenia zarządu menedżerskiego. Jednak należy zwrócić uwagę na fakt, iż wprowadzenie takiego zarządu łączy się z koniecznością uwzględnienia specyfiki pracy kierowniczej. Dla podmiotów tych, bardzo ważne jest ustalenie proporcji pomiędzy zarządzaniem samorządowym, wyrażającym podmiotowość członków zrzeszenia a menedżerskim ukierunkowanym na sprawność i efektywność- będących podstawą konkurencyjności (Grzegorzewski, Dyka, 2000, s. 62).

Możliwość pozyskania do zarządu osób spoza grona członków spółdzielni tworzy m.in. tzw. kontrakt menedżerski, zwany często umową o zarządzanie (Gujski, 2000, s. 57, Małysz 2006, 45). Zawarty na zasadzie umowy cywilnoprawnej pomiędzy zleceniodawcą (przedsiębiorcą, właścicielem przedsiębiorstwa lub osobą reprezentującą) a zleceniobiorcą (wyspecjalizowanym menedżerem lub firmą zarządzającą), dotyczy świadczenia szeroko pojętych usług zarządzania bądź realizacji określonych zadań w odniesieniu do całej

\footnotetext{
${ }^{3}$ Management w spółdzielniach oznacza kierownictwo i obejmuje wszystkie osoby w firmie, które dysponują kompetencjami zarządczymi i decyzyjnymi, przy uwzględnieniu odpowiedniego poziomu i szczebla zarządzania. Menedżerem w spółdzielni może być kierownik o odpowiednich kwalifikacjach, wyspecjalizowany w zarządzaniu dużym przedsiębiorstwem lub grupą czynności.

${ }^{4}$ Rola może być zdefiniowana jako zbiór oczekiwań i obligatoryjnych (reguł) zachowania się ze strony osób o określonej pozycji. Stąd rozpatrując role menedżerskie, należy je postrzegać w kontekście zadań i funkcji wykonywanych przez menedżerów. W literaturze przedmiotu wyróżnia się, trzy podstawowe grupy ról menedżera: międzyludzkie, informacyjne i decyzyjne. Menedżerowie, którzy kierują organizacją muszą sprostać wielu wymaganiom, przyjmować na siebie wiele ról oraz posiadać odpowiednie umiejętności pozwalające na sprawną realizację tych ról oraz dostosowanie się do zmieniającej się sytuacji rynkowej.

${ }^{5}$ Jest to kadra kierownicza nazywana menedżerami.
} 
jednostki gospodarczej lub jej części. Kontrakt cywilnoprawny (niepracowniczy), w odróżnieniu od kontraktu tzw. pracowniczego (umowy o pracę), stwarza menedżerowi większą swobodę w wykonywaniu swoich zadań i ogranicza bieżący nadzór drugiej strony. $\mathrm{W}$ rezultacie umożliwia to menedżerowi wprowadzenie własnych metod zarządzania i podejmowanie decyzji bez większych ograniczeń. Świadcząc pracę, nie jest on limitowany kodeksowymi normami czasu pracy.

\section{Charakterystyka kompetencji menedżerskich}

Do nauk o zarządzaniu pojęcie kompetencji wprowadził, na początku lat 70. XX wieku D. McClelland (Adams, 1997, s. 52). Jako kolejny próbę zdefiniowania kompetencji podjął w 1982 roku R. E. Boyatzis (Boyatzis, 1982, s. 17-19). Ostatecznie, koncepcja zarządzania kompetencjami została sformułowana w latach 90 . XX wieku jako odpowiedź na wymóg nowych sposobów zarządzania $\mathrm{w}$ organizacjach uczących się i inteligentnych. Obecnie, trudno wyobrazić sobie funkcjonowanie każdej organizacji bez uwzględnienia kompetencji jej pracowników, zwłaszcza specjalistów i menedżerów. Stają się one bardzo ważnym źródłem wartości organizacji oraz trwałej przewagi konkurencyjnej w dynamicznie zmieniającym się otoczeniu.

Nie ma pełnej zgody co do tego, jakie konkretnie kompetencje powinny charakteryzować efektywnego menedżera. Ogromna rozmaitość stanowisk kierowników i podmiotów, którymi kierują - sprawia, że opisywanie ich kompetencji w sposób uniwersalny, ujednolicony byłoby niezasadne. Trzeba uwzględnić swoistość wymagań różnych szczebli zarządzania. To bowiem, co jest najważniejsze w pracy prezesa zarządu czy dyrektora naczelnego, najczęściej nie ma takiego znaczenia w wypadku kierowników pierwszej linii, i odwrotnie. Inna jest struktura kompetencji osób zarządzających na przykład produkcją, a inna ludzi zarządzających projektami czy finansami (Oleksyn, 2010, s. 168).

Wszyscy menedżerowie, niezależnie od poziomu kierowania, mają jednak kilka kompetencji wspólnych. Należą do nich kompetencje: osobiste, społeczne i menedżerskie. $\mathrm{W}$ niniejszym artykule zaproponowano podział kompetencji na:

- Osobiste - są związane z indywidualnym sposobem realizacji zadań. Poziom tych kompetencji wpływa na ogólną jakość wykonywanych zadań - decyduje o szybkości, jakości i zaangażowaniu w podejmowane działania.

- Społeczne - wpływają na sposób budowania i jakość relacji z innymi oraz sposób wykonywania zadań, związanych z takimi kontaktami. Poziom tych kompetencji decyduje o skuteczności współpracy, porozumiewania się i wywierania wpływu na innych.

- Stanowiskowe (menedżerskie i przywódcze) - są związane z zarządzaniem pracownikami i organizacjami. Dotyczą zarówno miękkich obszarów kierowania, organizacji pracy, jak i strategicznych aspektów zarządzania. Poziom tych kompetencji decyduje o skuteczności zarządzania.

W zależności od szczebla zarządzania i rodzaju działalności, znaczenie każdej z tych grup jest jednak inne. Po krótkiej dyskusji teoretycznej na temat kompetencji menedżerskich, w dalszej części opracowania zostaną przedstawione wstępne wyniki badań nad kompetencjami pożądanymi u kierowników spółdzielniach mleczarskich. 
Tabela 1. Struktura kompetencji kadry kierowniczej w spółdzielniach mleczarskich

Table 1. Structure of managerial competences in dairy cooperatives

\begin{tabular}{|c|c|c|}
\hline Kompetencje Osobiste & Kompetencje Spoleczne & Kompetencje Menedżerskie \\
\hline $\begin{array}{l}\text { Wiedza - wiedza na temat } \\
\text { aktualnych trendów rynkowych w } \\
\text { branży mleczarskiej, orientacja w } \\
\text { dziedzinie związanej z } \\
\text { wykonywaną pracą. } \\
\text { Wykształcenie i kwalifikacje } \\
\text { uprawniające do funkcjonowania } \\
\text { w gospodarce globalnej. }\end{array}$ & $\begin{array}{l}\text { Komunikatywność - zdolność do } \\
\text { jasnego i precyzyjnego wyrażania się. } \\
\text { Właściwe rozumienie wypowiedzi } \\
\text { innych osób, umiejętność słuchania i } \\
\text { porozumiewania się z pracownikami i } \\
\text { klientami spółdzielni. }\end{array}$ & $\begin{array}{l}\text { Motywowanie - budowanie } \\
\text { zaangażowania i pozytywnego } \\
\text { nastawienia pracowników do } \\
\text { realizacji zadań. Dbałość o } \\
\text { podnoszenie wiedzy i umiejętności } \\
\text { pracowników. Nadzór nad produkcją } \\
\text { i jakością. }\end{array}$ \\
\hline \multirow[t]{5}{*}{$\begin{array}{l}\text { Innowacyjność i elastyczność - } \\
\text { rozwój nowych wyrobów, ich } \\
\text { promocja i dystrybucja, } \\
\text { umiejętność funkcjonowania w } \\
\text { konkurencyjnej światowej } \\
\text { gospodarce. Dopasowanie działań } \\
\text { do zmieniających się wymogów } \\
\text { rynkowych oraz tworzenie } \\
\text { alternatywnych planów działania. }\end{array}$} & $\begin{array}{l}\text { Negocjowanie - wypracowanie } \\
\text { rozwiązań korzystnych dla stron } \\
\text { negocjacji i utrzymania pozytywnych } \\
\text { kontaktów. Umiejętność osiągania } \\
\text { satysfakcjonujących celów } \\
\text { negocjacyjnych. }\end{array}$ & $\begin{array}{l}\text { Myślenie analityczne - } \\
\text { projektowanie zakładów, ciągłe ich } \\
\text { modernizowanie w zależności od } \\
\text { potrzeb rynkowych, monitorowanie i } \\
\text { kontrolowanie produkcji z } \\
\text { elementami nowoczesnego } \\
\text { controllingu, podejmowanie decyzji } \\
\text { dotyczących powstawania i } \\
\text { likwidacji komórek, }\end{array}$ \\
\hline & $\begin{array}{l}\text { Rozwiązywanie konfliktów - } \\
\text { Radzenie sobie z sytuacjami } \\
\text { konfliktowymi poprzez osiąganie } \\
\text { satysfakcjonującego porozumienia. } \\
\text { Rozstrzyganie sporów wśród } \\
\text { współpracowników, w zespole oraz w } \\
\text { relacjach z klientami (wewnętrznymi i } \\
\text { zewnętrznymi). }\end{array}$ & $\begin{array}{l}\text { Myślenie strategiczne - orientacja } \\
\text { w meandrach gospodarki światowej, } \\
\text { analiza sytuacji oraz rozwój } \\
\text { spółdzielni, przewidywanie tendencji } \\
\text { rynkowych oraz zajmowanie miejsca } \\
\text { na nowych rynkach światowych. }\end{array}$ \\
\hline & $\begin{array}{l}\text { Rozwiązywanie problemów - } \\
\text { przeprowadzanie sprawnej i } \\
\text { bezawaryjnej produkcji wyrobów, } \\
\text { utrzymywanie, rozwój i doskonalenie } \\
\text { Systemu Zarządzania Jakością, } \\
\text { organizowanie przeglądów Systemu } \\
\text { Zarządzania Jakością., rozwiązywanie } \\
\text { problemów dotyczących jakości. }\end{array}$ & $\begin{array}{l}\text { Orientacja w biznesie - znajomość } \mathrm{i} \\
\text { rozumienie procesów biznesowych i } \\
\text { rynkowych istotnych dla działalności } \\
\text { spółdzielni mleczarskich. } \\
\text { Wykorzystanie wiedzy na temat } \\
\text { aktualnych trendów rynkowych w } \\
\text { spółdzielni mleczarskiej. }\end{array}$ \\
\hline & & $\begin{array}{l}\text { Orientacja na klienta - } \\
\text { kształtowanie odpowiednich relacji } \\
\text { biznesowych z klientami, } \\
\text { pozyskiwanie klientów. Uzgadnianie } \\
\text { i realizacja warunków umów z } \\
\text { klientami, terminowa realizacja } \\
\text { zamówień. }\end{array}$ \\
\hline & & $\begin{array}{l}\text { Przywództwo - stabilny rozwój } \\
\text { spółdzielni i osiąganie dobrych } \\
\text { wyników ekonomicznych, } \\
\text { wywiązywanie się z zobowiązań } \\
\text { wobec kontrahentów, inwestowanie } \\
\text { w rozwój spółdzielni i tworzenie } \\
\text { nowych miejsc pracy, troska o } \\
\text { poprawę warunków pracy } \\
\text { pracowników, nadzór na } \\
\text { prawidłowym przechowywaniem } \\
\text { produktów w magazynie } \\
\text { nabiałowym, regularne opłacanie } \\
\text { składek na rzecz Krajowej Rady } \\
\text { Spółdzielczej. }\end{array}$ \\
\hline
\end{tabular}

Źródło: opracowanie własne. 


\section{Specyfika kompetencji menedżerskich w spółdzielniach mleczarskich}

Na tym etapie prac wykorzystano metodę Panelu Ekspertów, pozwalającą zbudować rzetelny obraz wymagań kompetencyjnych dla różnych ról kierowniczych w spółdzielniach mleczarskich. Do utworzenia zestawu kompetencji zostało wykorzystane narzędzie „Profil Kompetencji” opracowane przez firmę doradczo- szkoleniową „Forfuture Consulting”. Opracowano pożądany zestaw kompetencji przyczyniających się do sprawnego i skutecznego działania kierowników poszczególnych działów (działu: skupu, produkcji, marketingu, handlu i księgowości). Rezultaty tych analiz zaprezentowano w tabeli 1. Zawarte są w niej kompetencje wspólne dla kierowników działów w spółdzielniach mleczarskich.

Przyjęto, że kompetencje menedżerskie stanowią zespół cech menedżera, obejmujących jego osobowość, wiedzę, umiejętności, postawy, doświadczenie i odpowiedzialność, które pozostają w związku przyczynowo-skutkowym z zachowaniami menedżera decydującymi o sprawnym i skutecznym zarządzaniu (Tyrańska, 2015, s.13). Wśród kompetencji menedżerskich eksperci zaproponowali wyodrębnienie kompetencji społecznych związanych ze stosunkiem do drugiego człowieka, kompetencji osobistych wyznaczonych cechami osobowymi i kompetencji menedżerskich polegających na sposobie realizacji roli kierowników. Istnieje bowiem przesłanka, że struktura kompetencji osobistych, społecznych i menedżerskich odzwierciedla wartości wyznawane przez menedżerów (przywódców) organizacji i związane $\mathrm{z}$ nimi dominujące techniki zarządzania i style przewodzenia (Czubasiewicz, Nogalski, 2010, s. 147).

Dla menedżerów (kierowników poszczególnych działów) spółdzielni mleczarskich wybrano 12 spośród 36 kompetencji. O nich możemy mówić, że są decydujące dla tej branży. Okazuje się, że od menedżerów spółdzielni mleczarskich wymaga się różnych kompetencji. Jedną $\mathrm{z}$ najważniejszych jest posiadana przez nich wiedza, która już w momencie zatrudnienia staje się kapitałem spółdzielni i tylko od zarządu i rady nadzorczej zależy, czy zostanie ona wykorzystana w efektywny sposób (Wyrzykowska, 2012, s. 26-35). Menedżerowie powinni być kierownikami zespołów zorientowanych na rezultaty oraz powinni zarządzać swoimi emocjami. Ponadto powinni posiadać szereg typowych kompetencji menedżerskich, takich jak: motywowanie, myślenie analityczne i strategiczne, orientacja w biznesie, oraz przywództwo.

Przedstawiona lista kompetencji menedżerskich nie jest oczywiście listą zamkniętą. Opracowanie listy wszystkich kompetencji zawodowych menedżerów jest niemożliwe, gdyż jak wcześniej podano, kompetencje są dynamiczne i zmienne w czasie, podlegają procesowi uczenia się. Każda organizacja powinna stworzyć własną listę pożądanych kompetencji dla swoich menedżerów (kadry zarządczej i menedżerskiej) w oparciu o stawiane przed nimi cele biznesowe (Boyatzis, 1982, s. 67).

\section{Podsumowanie}

Przemiany zachodzące w gospodarce światowej, jej koncentracja i globalizacja powodują, że spółdzielczość mleczarska musi nieustannie dostosowywać się do nowych wymagań. Jednym z wielu czynników, które należy brać pod uwagę przy ocenie sukcesu lub porażki przedsiębiorstwa spółdzielczego, funkcjonującego na rynku światowym, jest kadra kierownicza i jej kompetencje. Kompetentni menedżerowie mogą zapewnić nową jakość zarządzania, ponieważ z jednej strony potrafią optymalizować wykorzystanie zasobów 
organizacyjnych, a z drugiej posiadają umiejętność przewidywania i dostosowania się do zmian w otoczeniu (procesów globalizacji), w którym działa organizacja.

Wśród kompetencji menedżerskich $\mathrm{w}$ spółdzielniach mleczarskich wyodrębniono: kompetencje osobiste wyznaczone cechami osobowymi, kompetencje społeczne związane ze stosunkiem do drugiego człowieka i kompetencje menedżerskie polegające na sposobie realizacji roli kierowników. Warto podkreślić, że u menedżerów spółdzielni mleczarskich „środek ciężkości” kompetencji przesuwa się z szeroko rozumianego rolnictwa do ekonomii i zarządzania. Menedżerowie powinni posiadać szereg typowych kompetencji menedżerskich, takich jak: motywowanie, myślenie analityczne i strategiczne, orientacja w biznesie i orientacja na klienta oraz przywództwo.

Niniejsze opracowanie bazuje w dużej mierze na autorskich komentarzach i refleksjach, wynikających ze skonfrontowania doświadczeń branżowych $\mathrm{z}$ przeglądem literatury dotyczącej kompetencji współczesnej kadry menedżerskiej. Wstępna analiza wskazuje na potrzebę dalszych badań nad tym zagadnieniem. Ocena aktualnego poziomu kompetencji menedżerów spółdzielni mleczarskich jest niezbędna do poznania i ustalenia ewentualnych braków kompetencyjnych oraz podjęcia odpowiednich działań w tym zakresie.

\section{Literatura}

Adams, K. (1997). Interview with Dawid McClelland. Competency, 4.

Bodak, A., Cierniak- Emerych A. (2010). Menedżer w spółdzielczości a partycypacja pracownicza. Prace Naukowe Uniwersytetu Ekonomicznego we Wrocławiu, 115, 74-89.

Boyatzis, R. (1982). The Competent Manager: A Model for Effective Performance, New York, John Wiley\&Sons. Cioch, H. (2011). Prawo spółdzielcze. Lex a Wolters Kluwer Business, Warszawa.

Czternasty, W., Czyżewski, B. (2007). Struktury kierowania agrobiznesem w Polsce. AE, Poznań

Czubasiewicz, H., Nogalski, B. (2010). Rozwój kompetencji menedżerskich. Praktyka Pomorskich Firm. Prace Naukowe Uniwersytetu Ekonomicznego we Wrocławiu, 115, 141-147.

Dworniak, J., Pietrzak, M. (2014). Spółdzielczość mleczarska- specyfika ekonomiczna i rola rewizji finansowej w Nadzorze Korporacyjny. Studia Prawno-Ekonomiczne, 91(2), 68-78.

Dyka, S., Grzegorzewski P. (2000). Zarządzanie spółdzielnią. Centrum Doradztwa i informacji Difin, Warszawa

Filipowicz, G. (2014). Zarządzanie kompetencjami. Perspektywa firmowa i osobista. Warszawa: Oficyna Wolters Kluwer business.

Filipowicz, G. Kompetentny Menedżer. PARP. Pobrano 6 stycznia 2016 z: www.kompetencjemsp.parp.gov.pl.

Gujski, W. (2000). Kontrakty menedżerskie oraz inne umowy cywilnoprawne o świadczenie pracy. Wydawnictwo Liberta, Warszawa.

Małysz, F. (2006). Różne formy zatrudnienia, cz. 2, Nietypowe formy zatrudnienia. Biblioteczka Pracownicza, Warszawa.

Oleksyn, T. (2010). Zarządzanie kompetencjami. Teoria i praktyka. Oficyna a Wolters Kluwer Business, Wyd. II Warszawa.

Pietrzak, M., Roman M. (2014). W poszukiwaniu wzorca przemian w sektorze mleczarskim - model liberalny czy interwencjonistyczny? W: red. R. Ciborowski, R. Dziemianowicz, A. Kargol-Wasiluk, M. Zalesko Gospodarka- społeczeństwo-finanse w Europie Środkowo- Wschodniej w latach 1989-2014. Uniwersytet w Białymstoku, Białystok, 72-81.

Pocztowski, A. (2007). Zarządzanie zasobami ludzkimi. Strategie - procesy - metody. Wyd. II, Warszawa, PWE.

Tyrańska, M., (2015). Koncepcja systemu oceny kompetencji kadry menedżerskiej w przedsiębiorstwie. Wydawnictwo Uniwersytetu Ekonomicznego w Krakowie, Kraków.

Wyrzykowska, B. (2012). Przedsiębiorczość intelektualna jako kompetencja współczesnego menedżera. Zeszyty Naukowe SGGW, Ekonomika i Organizacja Gospodarki Żywnościowej, 100, 26-35. 